\title{
De uma transição à outra? Revisitando Transição em resumo, de Wanderley Guilherme dos Santos (1986)
}

\section{Christian Edward Cyril Lynch'}

\section{Por que "resumo"?}

O artigo de Wanderley Guilherme dos Santos publicado no primeiro número da Revista Brasileira de Ciências Sociais intitulado "Transição em resumo: do passado recente ao futuro imediato" (1986) comporta, como todo texto, diferentes formas de leitura. Uma delas é a histórica ou contextual, que situa o artigo no tempo em que foi publicado: o do nascimento da Nova República, no interregno entre o fim do regime militar (1985) e a promulgação da atual Constituição (1988). Nele, Wanderley curiosamente fazia, sem dizê-lo, um resumo de sua própria produção bibliográfica sobre o modelo político brasileiro desde sua tese de doutorado nos Estados Unidos (1969). Partindo de um ponto de vista científico que na prática se confundia com a defesa de um Estado de direito democrático, politicamente liberal e economicamente socialdemocrata, Wanderley sustentava diversas proposições. Em primeiro lugar, ele sustentava que a ideologia autoritária brasileira tinha majoritariamente natureza instrumental, defendendo um Estado forte e centralizado para promover a modernização do Brasil pelo alto. É o que se depreende de Ordem burguesa e liberalismo político (1978). Em segundo lugar, Wanderley sustentava que, datada do Império, essa orientação "autoritária instrumental" teria sido reelaborada na década de 1930 sob Getúlio Vargas, que criara um modelo socioeconômico corporativista voltado à expansão conservadora da cidadania em uma chave de tutela. É o argumento de Cidadania e

\footnotetext{
I Professor do Instituto de Estudos Sociais e Políticos da Universidade do Estado do Rio de Janeiro (IESP-UERJ) e da Universidade Veiga de Almeida (UVA). Pesquisador da Fundação Casa de Rui Barbosa (FCRB), do Conselho Nacional de Desenvolvimento Científico e Tecnológico (CNPq)e da Fundação de Amparo à Pesquisa do Estado do Rio de Janeiro (FAPERJ). Sócio honorário do Instituto Histórico e Geográfico Brasileiro (IHGB) e presidente do Instituto Brasileiro de História do Direito (IBHD). Editor da Revista Insight Inteligência. 
Justiça (1979). A natureza específica do regime militar, os meios de transitar para a democracia e os desafios que ela enfrentaria foram os temas que Wanderley abordou em Poder e Política: crônica do autoritarismo brasileiro (1978) e Crise e Castigo: partidos e generais na política brasileira (1987).

\section{Uma leitura do passado: a transição da ditadura para a democracia (1986)}

Conforme sugerido em seu título, Transição em resumo mobilizava e sintetizava as reflexões presentes em sua obra até aquele momento. Wanderley salientava, em primeiro lugar, a insuficiência do modelo socioeconômico criado por Vargas centralizado, acumulador, iníquo e regulador - para dar conta das intensas mudanças experimentadas pelo Brasil nas décadas anteriores, decorrentes da urbanização, do crescimento econômico e da reestruturação ocupacional: "A velha ordem regulada, fruto do acaso histórico associado às concepções políticas de Vargas e seus auxiliares, não possui reserva de elasticidade para acomodar as transformações que ela própria apascentou, ora de forma relativamente democrática, e mais frequentemente mediante intervenções autoritárias". A emergência da democracia plena, como desfecho de um longo processo de cinquenta anos de liquidação da antiga sociedade oligárquica, impunha conceber um novo desenho institucional, capaz de resolver e compatibilizar de forma produtiva as tensões e contradições do Brasil contemporâneo. Para tanto, cumpria reestruturar o sistema representativo, recalculando o peso dos antigos atores em face da emergência dos novos e levando em consideração novas formas de representação política, paralelas ao sistema partidário. Mas, sempre atento às peculiaridades da trajetória brasileira como país atrasado e periférico, Wanderley sublinhava que o desafio não seria enfrentado, reproduzindo simplesmente os padrões adotados meio século antes pela democracia nos países cêntricos. Embora a intensidade das demandas coletivamente formuladas no Brasil fosse análogo ao das democracias maduras, o modelo que estas havia adotado depois da Segunda Grande Guerra para resolvê-lo - a democracia social - estava em crise naqueles princípios da globalização que, como se sabe, duraria até o começo do século XXI. Wanderley alertava que o contexto de aumento de reivindicações em um contexto de escassez de recursos poderia resultar em um ambiente político de radical polarização: "Desconhecer que teremos de enfrentar dois conjuntos de problemas - os derivados do arcaísmo e aqueles característicos da modernidade -, e que a modernização só soluciona as questões arcaicas ao preço de suscitar outras em substituição, pode aumentar de muito o preço a pagar pela construção de uma ordem democrática mais justa".

\section{Uma potencial leitura do presente: a transição do bolsonarismo para uma democracia reestruturada (2022)}

Outra forma por que o artigo de Wanderley pode e merece ser lido, para além do histórico ou contextual, é como uma reflexão de segunda ordem que interpele a conjuntura atual do país. Há quinze anos, a transição a que Wanderley aludia em seu artigo de 1986 parecia concluída com êxito, com a democracia brasileira enraizada graças ao pacto realizado entre velhos atores - Estado, empresários, sindicatos e partidos - com novos - os movimentos sociais - que parecia ter 
logrado promover crescimento fiscalmente responsável com redução das desigualdades sociais. Lido em 2007, seu artigo teria interesse principalmente histórico. Entretanto, diante da crise da democracia iniciada em 2013, decorrente da insuficiência do sistema representativo organizado entre 1988-1994, e da alternativa de um populismo reacionário de tintas neofascistas, calcado no ativismo social de extrema direita de caráter plebiscitário, nostálgico da ditadura militar, torna-se sedutora, por analogia, a ideia de renovar os esforços de Wanderley nas décadas de 1970-1980. Escrita pelo pensador por excelência de nossa democracia contemporânea, Transição em resumo constitui um modelo de análise de conjuntura fundamentada do ponto de vista teórico e empírico, resultante de um projeto de pesquisa que, devidamente adaptado, poderia ser hoje renovado. Seria preciso indagar, em primeiro lugar, os efeitos da globalização no aprofundamento das desigualdades sociais, seguidas por sua crise e pelo retorno de um nacionalismo reativo, defensivo e conservador; em segundo lugar, as origens do populismo antidemocrático representado pelo neofascismo ou reacionarismo contemporâneo; em terceiro lugar, as consequências do advento, no contexto da relação entre centro e periferia, de uma sociedade pós-industrial marcada pela automação, pela informatização e pelo impacto das redes sociais na organização e na comunicação políticas. Por fim, seria preciso verificar como todas essas transformações repercutiram em um Brasil de maior mobilidade social e escolaridade, que se tornou menos católico que evangélico, mas que também sofreu mudanças na distribuição espacial das riquezas em suas regiões e se desindustrializou. Todo esse esforço permitiria avaliar, enfim, as condições de possibilidade de reestruturação da nossa democracia representativa, levando em consideração as mudanças sociais e econômicas ocorridas no mundo e no Brasil nos últimos vinte anos.

\section{Conclusão em resumo}

Em síntese, Transição em resumo merece ser relido por três motivos diferentes. Primeiro, porque serve para compreender a história da democracia brasileira e do papel nela exercido por nossa ciência política na década de 1989. Segundo, porque se trata de um modelo de análise de conjuntura bem fundamentada do ponto de vista empírico e teórico. Por fim, porque esse modelo ainda hoje se presta, com as devidas atualizações, para pensar as causas da insuficiência do modelo democrático elaborado em 1988-1994 e as possibilidade de uma nova transição que, superando a nova ameaça autoritária, conclua pela restauração de nossa democracia em bases renovadas, dotando-a de instituições capazes de melhor refletir e filtrar as novas demandas sociais emergidas nos últimos vinte anos.

\section{REFERÊNCIAS BIBLIOGRÁFICAS:}

SANTOS, Wanderley Guilherme dos (1978), Ordem burguesa e liberalismo político. São Paulo, Duas Cidades.

SANTOS, Wanderley Guilherme dos (1978). Poder e Política: crônica do autoritarismo brasileiro. Rio de Janeiro: Forense-Universitária. 


\section{bib}

SANTOS, Wanderley Guilherme dos (1979). Cidadania e Justiça: a política social na ordem brasileira. Rio de Janeiro, Campus.

SANTOS, Wanderley Guilherme dos (1987). Crise e castigo: partidos e generais na política brasileira. São Paulo/Rio de Janeiro, Vértice/IUPERJ. 


\section{Resumo}

De uma transição à outra? Revisitando Transição em resumo, de Wanderley Guilherme dos Santos (1986)

Comentário crítico sobre o artigo "Transição em resumo: do passado recente ao futuro imediato", de Wanderley Guilherme dos Santos, publicado no primeiro número da Revista Brasileira de Ciências Sociais (RBCS) em 1986.

Palavras-chaves: Transição democrática; Wanderley Guilherme dos Santos, Nova República; democracia brasileira

Abstract

From one transition to another? Revisiting Transition in Brief, by Wanderley Guilherme dos Santos (1986)

Critical comment on the article "Transition in summary: from the recent past to the immediate future", by Wanderley Guilherme dos Santos, published in the first issue of the Revista Brasileira de Ciências Sociais (RBCS) in 1986.

Keywords: Democratic transition; Wanderley Guilherme dos Santos, New Republic; brazilian democracy 